Toni Paspalovski ${ }^{1}$, Vangelica Jovanovska ${ }^{2}$

${ }^{1}$ ELEM-Skopje, Macedonia

${ }^{2}$ Faculty of Biotechnical Sciences - Bitola, Bitola, Macedonia

\title{
Partial Replacement of the Active Steel on the Turbogenerator End Zone
}

Original scientific paper

\begin{abstract}
In this paper is described one practical example of the replacement (reconstruction) of the active steel end zone of the turbo-generator $n .1$ which operates in REK Bitola, with purpose to improve the condition of the turbo-generator from magnetic point of view during the modernization for increasing the power. Turbo-generator is type TVV 200-2A produced by "Elektrosila", Russia. The stator winding is cooled directly with distillate. The rotor winding, the stator core, and the housing are cooled with hydrogen. The reconstruction itself covers replacing more elements which are: - Replacement of five end packs of each active steel end zone, which are manufactured in monolithic (backed) version and with successive reducing of its height.

- Reconstruction of the pressure rings with simultaneous installation of new enlarged copper screen on the pressure rings.

- Additional fingers for better tightness and intensifying the cooling of the end zones - Stabilization of the pressing tightness of turbo-generator core active steel with installing special spring devices so called pressure accumulators.

During the realization of the reconstruction special tools, devices and equipment have been used. Also for all examination which have been done protocols (test reports) have been made. Every test report consist from: test object, basis, criteria of control, test results and conclusion on the test results.
\end{abstract}

Key words: turbogenerator, replacement, end packs

\section{Introduction}

Turbo-generator long-term operation is characterized by active steel degradation processes. Under the influence of temperatures, electrical field strength, mechanical impact, and vibration effects, cooling media influence the aging of active steel, insulation, conductors take place. As a rule, most of damages occurs on active steel in end zone of the stator core. Pressing slackness results in individual lamination vibrations, its breakage with consecutive damage of stator winding main insulation and inadmissible overheating of toothing on bore surface. Sudden failures become more frequent and cause considerable loss due to downtime and recovery.

\footnotetext{
* Corresponding author: e-mail: timjugo@t-home.mk
} 
All turbo-generators, which work beyond the bounds of their specified life, have reduced possibilities in operation under maximum load conditions and under reactive power duty because of inadequate condition of active steel end zones.

One of cardinal solutions for turbo-generator renewal and its service life extension consists in modernization of the stator with its rewinding and partial active steel replacement.

This modernization was done on the generators type TVV-200-2A in TPP Bitola, and is subject of this paper.

\section{Analysis}

\section{Description of the reconstruction}

The reconstruction itself is done by replacing more elements [2] which are:

- Replacement of five end packs of each active steel end zone, which are manufactured in monolithic (backed) version and with successive reducing of its height from inside towards the ends.

For reducing the loses and heating of the stator core so called "magnetic shunt" is applied. It represents special packs from electro-technical steel, similar to the packs from the basic core, but in length of $36.5 \mathrm{~mm}$ first, $31 \mathrm{~mm}$ second, $24 \mathrm{~mm}$ third, $18 \mathrm{~mm}$ forth, and $18.5 \mathrm{~mm}$ the fift pack from the inside towards the end with hard pressure with fingers (fig. 1). The way they are placed these packs do not change the basic magnetic flow, but they short circuit the axial flows from dispersing on the end parts of stator winding with cutting from pressure cooper screen. For better ventilation of the magnetic shunt, magnetic shunt itself is separated from basic core with pressure fingers.

On fig. 2 monolithic (backed) packs which were mounted on the end parts of the stator magnetic core of turbo-generator n. 1 in TPP Bitola are presented. As it can be seen packs are reducing in diameter going from the inside towards the end of the core but they are also reducing in thickness in the same direction.

On fig. 3 modernized end part of the magnetic stator core of turbo-generator $n .1$ in TPP Bitola is presented.

- Reconstruction of the pressure rings with simultaneous installation of new enlarged copper screen on pressure rings. Active steel end zone manufacturing as a "magnetic

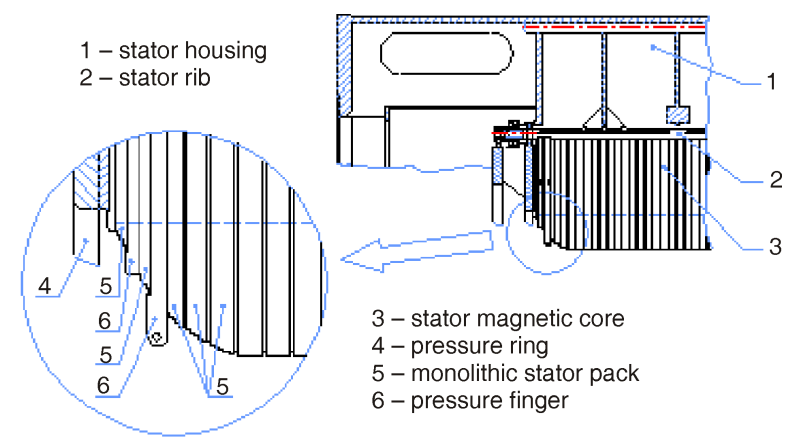

Figure 1. Modernized end part of stator magnetic core for turbo-generator n.1 in TPP Bitola 
shunt" with simultaneous installation of new enlarged copper screen on pressure rings ensures low temperatures under reactive power consumption conditions.

- Additional fingers for better tightness and intensifying the cooling of the end zones.

- Stabilization of the pressing tightness of turbo-generator core active steel with installing special spring devices so called pressure accumulators.

In the process of the turbo-generator operation the core tightness may loosen as a result of working influences on the active steel end zone (i.e., temperature, vibration).

The efficient method of restoring the active steel tightening force at the first and the second loosening stages is the installation of special spring devices having the specified and adjustable pressure under the core tightening nuts(fig. 5).

The spring blocks (pressure accumulators all together 20 from each side of the core) are mounted after carrying out the works on the teeth local repairs and additional works ensuring the core pressure rings movability.

The technology of mounting the pressure accumulators has its own peculiarities, which lie in observing the measures for preventing the penetration of particles of steel parts machined into the stator winding (into the slot part and end winding)

On fig. 6 one pressure accumulator which has been mounted on turbo-generator n.1 in TPP Bitola is presented.

Into the process of mounting the pressure accumulators the measurement aimed at detection of short-circuits between active steel partial laminations shall be performed. For this purpose the most appropriate is the active steel test at low induction densities (ELCID).

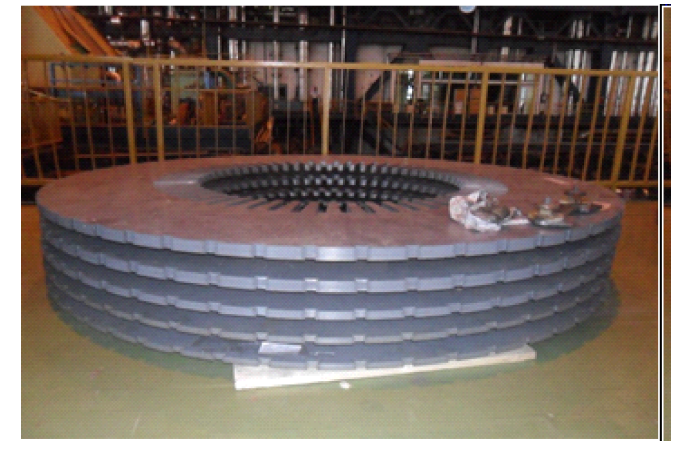

Figure 2. Monolithic packs for replacement of the end part of stator magnetic core for turbogenerator n.1 in TPP Bitola

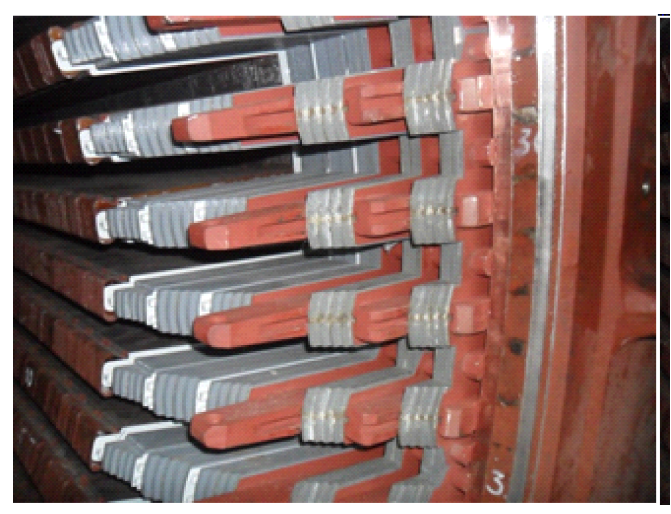

Figure 3. Modernized end part of the magnetic stator core of turbo-generator n. 1 in TPP Bitola

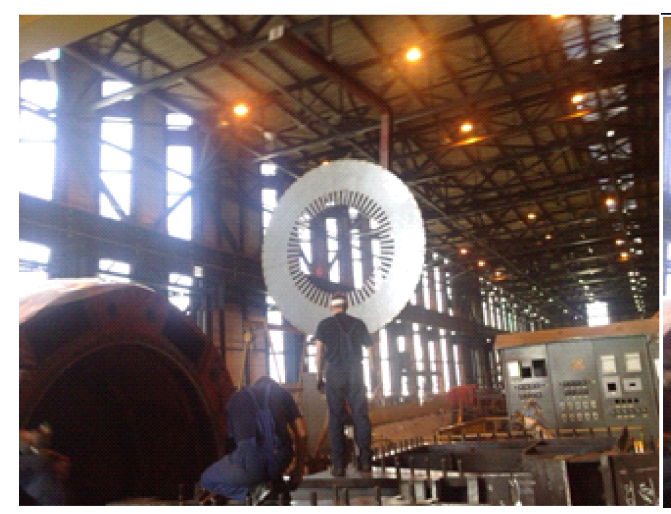

Figure 4. Monolithic end pack of the stator magnetic core in the process of mounting for turbo-generator n. 1 in TPP Bitola 


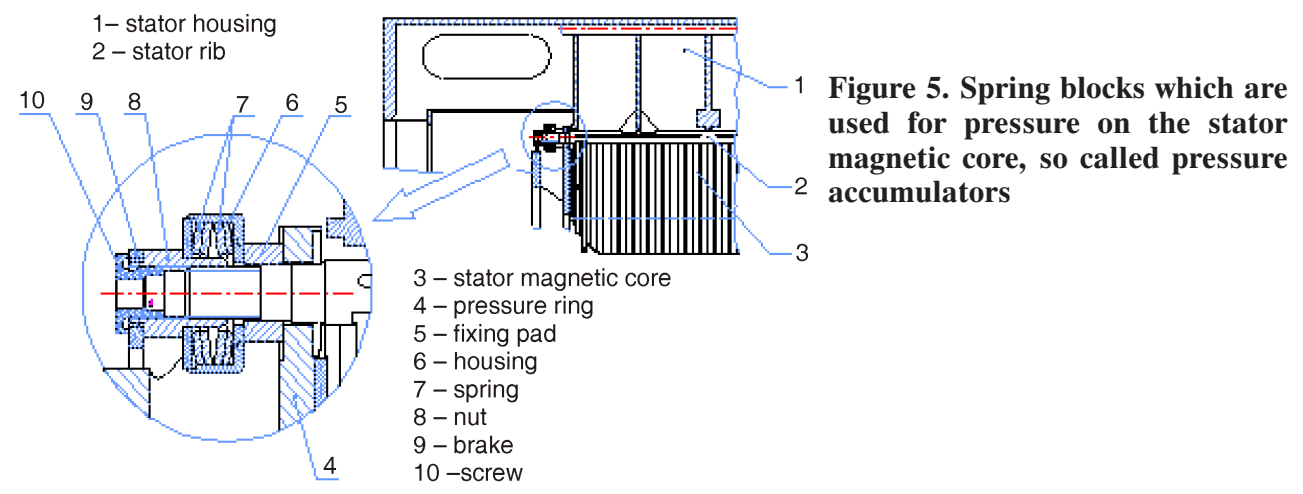

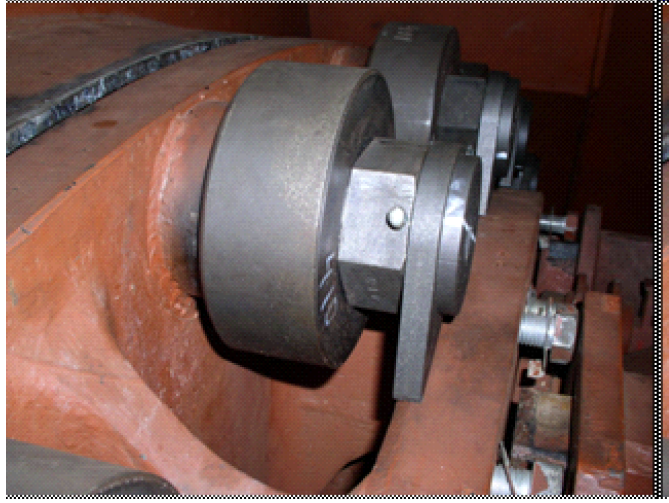

Figure 6. Pressure accumulator mounted on turbogenerator $\mathrm{n} .1$ in TPP Bitola

\section{Realization of the reconstruction}

Reconstruction, that is to say replacement of the end packs from magnetic stator core was done successive and during the performance of the operations special equipment and contemporary diagnostic methods were used. Also, examinations were made for assessment of technical conditions of the turbo-generator stator core before and after the reconstruction.

For all examinations protocols (test reports) were made. In every protocol exactly is known: test object, basis, crite-

ria of control, used equipment, test results, and conclusion on the test results. Examinations which were carried out during the reconstruction were:

(1) Check of core linear dimensions

- core dimensions before disassembly,
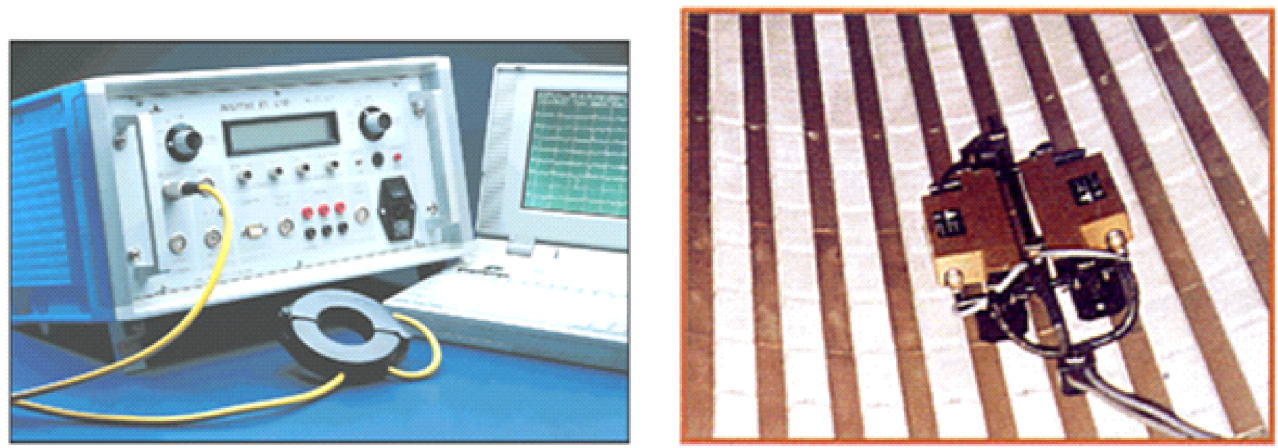

Figure 7. Instrument ELCID and probes in process of electromagnetic control of stator core 
- thickness of the newly installed packs, exciter side,

- thickness of the newly installed packs, turbine side, and

- core dimensions in pressed condition.

(2) Electromagnetic inspection of active iron lamination faults by using automatic inter-lamination fault monitoring system (ELCID) according to [5] standard IEEE 62.2-2004 in which current bigger than $100 \mathrm{~mA}$ while induction in yoke is $4 \%$ from nominal one, indicates isolation disturbance.

(3) Core ring flux test (for heating and loses) [3] with measurement of core bore surface temperature using infra-red equipment according to which:

- biggest allowed core teeth heat-

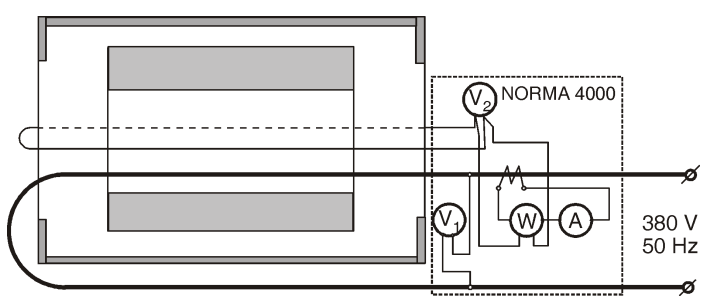

Figure 8. Connection scheme for core ring flux test

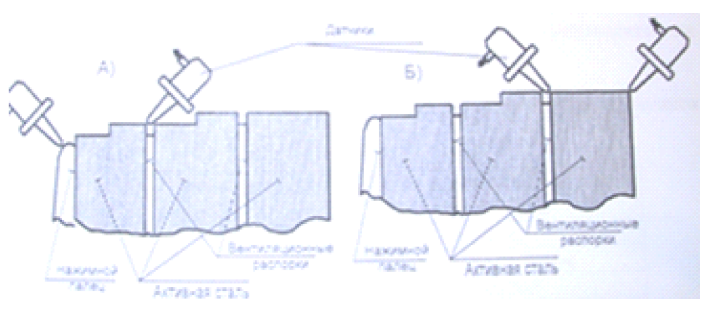

Figure 9. Handling the probes for measurement of: (a) pressure finger - pack and (b) pack from tooth ing $25^{\circ} \mathrm{C}$,

- biggest allowed difference of heating the teeth compared to core $15^{\circ} \mathrm{C}$, and

- specific loses when induction is $1.4 \mathrm{~T}$ should not be bigger than $2.2 \mathrm{~W} / \mathrm{Kg}$.

The examinations were carried out with current of $400 \mathrm{~A}, 50 \mathrm{~Hz}$ from $0.4 \mathrm{kV}$ source with one magnetization winding around the core, one control winding and induction of $1 \mathrm{~T}$ in duration 72 minutes according to the following scheme.

For discovering the hot spots infra-red digital camera type IR928 was used while for measurement of the loses power analyzer type NORMA 4000 was used.

(4) Visual control of the yoke and the elements of reinforcements of the magnetic core (magnifying glass $4 \mathrm{x}$ and hammer $400 \mathrm{~g}$ were used).

Ultrasonic control of the tightness of the pressured stator core according to criteria from the instruction [1] "Conduction of overhaul and modernization of the active steel with using contemporary methods for diagnostics and technical control of the condition of the stator of the turbo-generator" i.e., average value of the velocity of the wave on $1 \mathrm{~mm}$ length of the packs for monolithic (backed) and ordinary packs (in $\mu \mathrm{s} / \mathrm{mm})$ :

- good condition of the teeth: less than 0.8 for backed 1.5 for ordinary,

- satisfactory condition of the teeth: 0.8-1.2 for backed, 1.5-2 for ordinary,

- initiation of loosening the tightening force:1.2-1.8 for backed 2-2.5 for ordinary, and

- loosened tightness: bigger than 1.8 for backed and 2.5 for ordinary.

For the system of pressure finger-pack:

- good condition: less than $15 \mu \mathrm{s}$, and

- satisfactory condition: less than $20 \mu \mathrm{s}$.

(Ultrasonic defectoscope with frequency of $60 \mathrm{~Hz}$ type YD2N-PM and complete of probes were used) 
(5) Technical examinations for determining the condition of the pressure accumulators which consist of: (a) condition of the stator core, (b) position of the pressure ring of the stator core towards the housing, (c) correction of the clearance between the pressure ring and the stator housing, (d) Installation (setting) of the pressure accumulators with special hydraulic equipment with force of 1 ton, which is equal to the pressure of the stator core of $18 \mathrm{~kg} / \mathrm{cm}^{2}$, (e) control of the tightness of the pressure accumulators, (f) position of the pressure ring of the stator core towards the housing after tightening the pressure accumulators, and (g) subseque nt.

Change in the absolute distances that people and freight travel. While this is conceptually the most straightforward of the ways to affect greenhouse gas emissions from transport, it is often the most difficult to put into practice. This is because reducing transport activity requires individuals to change their behavior. Some examples of technologies and policies that could produce activity reductions are optimizing logistics for goods delivery, telecommuting, and designing compact towns and cities with mixed-use zoning.

\section{Conclusions}

Taking into consideration that with this reconstruction of the end packs of the stator core work of the generator in regime of under-excitation is allowed and knowing that the thermo power plant Bitola is at the big distance from the consumption of the energy, conduction of the modernization is obligatory.

Also, this reconstruction is a part of a complete modernization which involves replacement of the stator winding and reconstruction or complete replacement of the rotor with the new one. It must be emphasized that this reconstruction is performed only if complete replacement of stator winding was planned in advance. If complete replacement of stator winding was not planned in advance, this reconstruction should not be performed because of the real risks of possible damages on the stator winding as a result its removing and putting it back.

Magnetic shunt reduces the heating of the end packs stator core 2-3 times compared to the basic construction. It also allows generator work in capacitive regime, that is to say regime of under-excitation without large heating of the end packs of the stator core.

Effectiveness of modernization:

- service reliability of the generator is improved,

- operational characteristics range of the generator is enlarged including operation with more profound reactive power consumption,

- stator service life is extended by 15 years (120,000 working hours),

- overhaul life is 6 years (50,000 working hours), and

- availability factor of the turbo-generator is increased.

\section{References}

[1] ***, Quality Assurance Program in the Process of TVV-200-2A -Type Turbogenerator Stator Renovation

[2] ***, Technological Requirements for end Packs Replacement of TVV-200-2A Turbogenerator Stator Core

[3] ***, OBS.460.247.TO Type TVV-200-2A Three-Faze Synchronous Turboalternerator for TPP Bitola, Technical Description and Service Manual 
[4] Kerszenbaum, I., IEEE Power Engineering Series, Inspection of Large Synhronous Machines, Checklists, Failure Identifications and Troubleshooting

[5] ***, Standard IEEE 62.2-2004 Guide for Diagnostic field Testing of Electric Power Apparatus - Electrical Machinery

[6] Paspalovski, T., Increase the Active Power on Large Turbogenerators with Review Type TVV-200-2A, Ph. D. thesis, Bitola, Macedonia, 2012

\section{Апстракт}

Тони ПАСПАЛОВСКИ, Вангеелица ЈОВАНОВСКА

${ }^{1}$ ЕЛЕМ-Скопље, Македонија

${ }^{2}$ Факултет биотехничких наука, Битољ, Македонија

\section{Процес замене крајева статорског магнетног језгра турбогенератора}

У овом раду изнет је један практичан пример за замену (реконструкцију) крајних пакета из статорског магнетног језгра турбогенератора број 1 у Термоелектрани у Битољу, при реализацији модернизације у циљу повећања активне снаге. Турбогенератор је типа TVV-200-2A произведен у "Електросила", Русија са статорским намотајима који се хладе директно са дестилованом водом, док се роторски намотај, магнетно једро и кучиште хлади се гасом-водоником.

Реконструкција је обухватила замену више елемената и то:

- замену крајних пет пакета са обе стране магнетног језгра монолитне конструкције са значајним смањењем висине пакета,

- реконструкцију потисне плоче са уметањем бакарног прстена,

- уметање додатних прстију због причврштавања и повећавања хлађења крајних пакета, и

- стабилизацију дихтовања језгра турбогенератора са постављањем специјалне навртке са константним притиском.

При реализацији реконструкције су употребљене специјалне конструкције и примењене савремене методе за дијагностику и контролу карактеристике као старе изведбе (пре замене) тако и после извршене реконструкције.

За сва извршена испитивања направљени су протоколи у којих се тачно зна: циљ испитивања, употребљених апарата, инструмената и ко је извршио мерења.

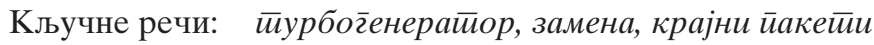

* Одговорни аутор; електронска адреса: timjugo@t-home.mk 